University of Nebraska - Lincoln

DigitalCommons@University of Nebraska - Lincoln

\title{
Comparison of Percent Hatch and Fungal Infestation in Channel Catfish Eggs after Copper Sulfate, Diquat Bromide, Formalin, and Hydrogen Peroxide Treatment
}

\author{
Andrew J. Mitchell \\ United States Department of Agriculture, drew.mitchell@ars.usda.gov \\ David L. Straus \\ United States Department of Agriculture \\ Bradley Farmer \\ United States Department of Agriculture \\ Ray Carter \\ United States Department of Agriculture
}

Follow this and additional works at: https://digitalcommons.unl.edu/usdaarsfacpub

Part of the Agricultural Science Commons

\begin{abstract}
Mitchell, Andrew J.; Straus, David L.; Farmer, Bradley; and Carter, Ray, "Comparison of Percent Hatch and Fungal Infestation in Channel Catfish Eggs after Copper Sulfate, Diquat Bromide, Formalin, and Hydrogen Peroxide Treatment" (2010). Publications from USDA-ARS / UNL Faculty. 572.

https://digitalcommons.unl.edu/usdaarsfacpub/572
\end{abstract}

This Article is brought to you for free and open access by the U.S. Department of Agriculture: Agricultural Research Service, Lincoln, Nebraska at DigitalCommons@University of Nebraska - Lincoln. It has been accepted for inclusion in Publications from USDA-ARS / UNL Faculty by an authorized administrator of DigitalCommons@University of Nebraska - Lincoln. 


\title{
Comparison of Percent Hatch and Fungal Infestation in Channel Catfish Eggs after Copper Sulfate, Diquat Bromide, Formalin, and Hydrogen Peroxide Treatment
}

\author{
Andrew J. Mitchell, * David L. Straus, Bradley Farmer, and Ray Carter \\ U.S. Department of Agriculture, Agricultural Research Service, Harry K. Dupree Stuttgart National \\ Aquaculture Research Center, Post Office Box 1050, 2955 Highway 130 East, Stuttgart, Arkansas 72160, USA
}

\begin{abstract}
Reduced survival of fish eggs is often a result of infestation with fungi Saprolegnia spp. However, timely chemical treatments often limit these infestations and increase survival. The effect of copper sulfate pentahydrate (CSP; $10 \mathrm{mg}$ of CSP/L of water), diquat bromide ( $25 \mathrm{mg}$ of diquat cation/L), formalin $(433 \mathrm{mg} / \mathrm{L})$, and hydrogen peroxide $\left(\mathrm{H}_{2} \mathrm{O}_{2} ; 250 \mathrm{mg} / \mathrm{L}\right)$ on percent hatch and fungal infestation in eggs of channel catfish Ictalurus punctatus was compared in two identical trials (five replicates for each chemical treatment per trial). The percent hatch in all chemical treatments was significantly better than percent hatch of the controls. The amount of fungal coverage on egg masses treated with CSP, formalin, and $\mathrm{H}_{2} \mathrm{O}_{2}$ was significantly less than that observed on the controls. Although not statistically different from the other treatments, $\mathrm{H}_{2} \mathrm{O}_{2}$ at $250 \mathrm{mg} / \mathrm{L}$ exhibited the highest average percent hatch $(64 \%$; control hatch $=34 \%)$, the lowest fungal coverage $(1.5 \mathrm{~cm}$; control coverage $=7.2 \mathrm{~cm})$, and the lowest occurrence of fungi $(50 \%$; control occurrence $=100 \%$ ) among the treatments.
\end{abstract}

A number of chemicals, including formalin (Walser and Phelps 1994), diquat bromide (Mitchell 1983), copper sulfate pentahydrate (CSP; Straus et al. 2009a), and hydrogen peroxide $\left(\mathrm{H}_{2} \mathrm{O}_{2}\right.$; Gaikowski et al. 2003; Small and Wolters 2003; Mitchell et al. 2009), have been tested for efficacy against aquatic fungal infestation (Saprolegniaceae, usually members of the genus Saprolegnia or Achlya) in eggs of channel catfish Ictalurus punctatus (Neish and Hughes 1980; Tucker and Robinson 1990). Formalin (New Animal Drug Application [NADA] number 141-255) and $\mathrm{H}_{2} \mathrm{O}_{2}$ (NADA numbers 137-687, 140-989, and 200414) have Food and Drug Administration (FDA) labels for 15-min treatments against external saprolegniasis on warmwater finfish eggs at a rate of $1,000-2,000 \mathrm{mg} /$ $\mathrm{L}$ of water for formalin and $750-1,000 \mathrm{mg} / \mathrm{L}$ for $\mathrm{H}_{2} \mathrm{O}_{2}$. Diquat and CSP are not labeled for use on eggs with fungi, but efforts are underway at the Harry K. Dupree Stuttgart National Aquaculture Research Center (HKDSNARC) to obtain an FDA label for copper sulfate on channel catfish eggs (Straus et al. 2009b). Except for $\mathrm{H}_{2} \mathrm{O}_{2}$, there are few data concerning the use of these chemicals on channel catfish eggs. Even with the available data, it is difficult to evaluate and compare optimal treatment rates or to determine the most effective treatment chemical because the data were produced using different application methods, hatching systems, egg manipulations, water tempera-

\footnotetext{
* Corresponding author: drew.mitchell@ars.usda.gov
}

Received September 28, 2009; accepted November 27, 2009 Published online March 25, 2010 tures, water exchange rates, and egg densities, and key information is sometimes missing from the reports. Additionally, the combined influences of these differences would be difficult to separate.

Walser and Phelps (1994) reported that two immersion-flush treatments (i.e., chemical is applied en masse and slowly dissipated with constant water flow; commonly used in commercial channel catfish hatching troughs) with formalin applied at $400 \mathrm{mg} / \mathrm{L}$ each day in aquaria (egg density $=1.25 \mathrm{~g}$ of eggs/L) gave the highest percent hatch ( $94 \%$ compared with $4 \%$ for controls) and were most effective in controlling Saprolegnia spp. Range-finding studies in our laboratory (D.L.S. and A.J.M., unpublished data) suggest that once-daily immersion-flush (2 water exchanges/h) formalin treatments at or above $434 \mathrm{mg} / \mathrm{L}(400 \mathrm{mg} / \mathrm{L}$ when specific gravity is not taken into account) prevented all fungal growth in experimental hatching troughs (egg density $=2.5 \mathrm{~g} / \mathrm{L}$ ). Under the conditions of these studies, the labeled formalin rates $(1,000$ $2,000 \mathrm{mg} / \mathrm{L}$ ) appear to be higher than needed. Mitchell (1983) found that diquat bromide applied at $25 \mathrm{mg}$ of diquat cation/L in a 10-min static-bath treatment was effective in limiting fungal growth on channel catfish eggs in experimental hatching troughs. Recent work (D.L.S. and A.J.M., unpublished data) demonstrated that immersion-flush (2 water exchanges/h) diquat bromide treatments at $25 \mathrm{mg} / \mathrm{L}$ applied daily in troughs (egg density $=2.5 \mathrm{~g} / \mathrm{L})$ produced $70 \%$ hatch $(37 \%$ for controls), whereas diquat bromide treatments at 50 and $100 \mathrm{mg} / \mathrm{L}$ did not increase hatch. Straus et al. (2009a) reported that the optimal immersion-flush CSP treat- 
ment ( 2 water exchanges/h) was $10 \mathrm{mg} / \mathrm{L}$ applied daily in experimental hatching troughs (egg density $=2.5 \mathrm{~g} /$ L); percent hatch was $69 \%$ ( $2 \%$ for controls). Higher treatment concentrations did not increase hatch rates, and little fungal growth was observed at a CSP concentration of $10 \mathrm{mg} / \mathrm{L}$ or higher.

Several studies demonstrated that $\mathrm{H}_{2} \mathrm{O}_{2}$ increased survival of channel catfish eggs and prevented fungal growth; however, different experimental conditions produced a wide range of optimal treatment rates. Rach et al. $(1998,2004)$ reported that daily $15-\mathrm{min}$, continuous-flow immersions (i.e., chemical is administered at a constant rate to the incoming water) with $\mathrm{H}_{2} \mathrm{O}_{2}$ at $1,000 \mathrm{mg} / \mathrm{L}$ in small aquaria (egg density = $25-30 \mathrm{~g} / \mathrm{L}$ ) and at $750 \mathrm{mg} / \mathrm{L}$ in egg hatching jars (egg density $=130 \mathrm{~g} / \mathrm{L})$ produced $78 \%$ and $69 \%$ hatch survival (19\% and $44 \%$ for controls), respectively; fungus control was reported in the 1998 study. At the other extreme, Small and Wolters (2003) showed that daily immersion-flush treatments (1.2 water exchanges/ h) with $\mathrm{H}_{2} \mathrm{O}_{2}$ at $70 \mathrm{mg} / \mathrm{L}$ in troughs (egg density $=1 \mathrm{~g} /$ L) produced the highest hatch percentage $(68 \%$ versus $24 \%$ for controls). Small (2004) documented that at $24^{\circ} \mathrm{C}$ and $28^{\circ} \mathrm{C}$, the highest egg hatching success was from daily 15 -min static-bath treatments in aquaria at $\mathrm{H}_{2} \mathrm{O}_{2}$ concentrations of 500 and $100 \mathrm{mg} / \mathrm{L}$, respectively (about 60\% survival was observed for both treatments versus $<35 \%$ for the controls). Mitchell et al. (2009) found that daily immersion-flush treatments ( 2 water exchanges $/ \mathrm{h}$ ) at $250 \mathrm{mg} / \mathrm{L}$ in experimental troughs (egg density $=2.5 \mathrm{~g} / \mathrm{L}$ ) produced the best fungal control and percent hatch $(64 \%$ versus $25 \%$ for control). In a preliminary trial from the same study, egg hatch was $10.7 \%$ at an $\mathrm{H}_{2} \mathrm{O}_{2}$ concentration of 1,000 $\mathrm{mg} / \mathrm{L}$ and $42.8 \%$ at $250 \mathrm{mg} / \mathrm{L}$, indicating that the $1,000-\mathrm{mg} / \mathrm{L} \mathrm{H}_{2} \mathrm{O}_{2}$ treatment may be toxic under these study conditions. Under the conditions of three of these studies (Small and Wolters 2003; Small 2004; Mitchell et al. 2009), the labeled $\mathrm{H}_{2} \mathrm{O}_{2}$ concentrations (750$1,000 \mathrm{mg} / \mathrm{L}$ ) were higher than needed.

Although information from multiple experiments is not available for formalin, CSP, and diquat bromide treatments of channel catfish eggs, it is likely that the differences seen in the $\mathrm{H}_{2} \mathrm{O}_{2}$ studies would occur with these three chemicals if subjected to the same study design and methodology variations. To allow comparison between treatments, optimum rates have to be determined under similar experimental conditions; the optimal rates can then be compared together in a study using similar design and methodology.

The purpose of this study was to compare, in the same experiment, the percent hatch and antifungal effectiveness of once-daily immersion-flush treatments with CSP, diquat bromide, formalin, or $\mathrm{H}_{2} \mathrm{O}_{2}$ applied to channel catfish eggs that were naturally infested with aquatic fungi in an experimental, compartmentalized trough hatching system. The four chemicals were selected because the HKDSNARC has a history of testing these chemicals against channel catfish eggs infested with fungi, and all were shown to increase egg survival and reduce the incidence of fungi. Concentrations used in this study for formalin $(433 \mathrm{mg} / \mathrm{L})$, diquat bromide $(25 \mathrm{mg} / \mathrm{L}), \mathrm{CSP}(10 \mathrm{mg} / \mathrm{L})$, and $\mathrm{H}_{2} \mathrm{O}_{2}(250$ $\mathrm{mg} / \mathrm{L}$ ) were selected from optimal rates previously mentioned and determined in an experimental trough hatching system using a study design and methodology similar to those used in the present study. It is recognized that the formalin and $\mathrm{H}_{2} \mathrm{O}_{2}$ rates tested in this study are less than the concentrations listed on FDA labels.

\section{Methods}

Two identical trials with five replicates for each treatment and a control were run sequentially. For each trial, five of the healthiest-looking channel catfish egg masses $(>700 \mathrm{~g}$, no visible fungi or discolored areas, $<24$ h old) were selected from spawns produced at the HKDSNARC hatching facility and were transported to the research laboratory in aerated water. Individual egg masses were then separated by hand into five nearly equal portions (mean $\pm \mathrm{SD}, 90.3 \pm 6.4 \mathrm{~g}$ ), and single portions were placed into individual baskets located in individually plumbed hatching compartments that held $35 \mathrm{~L}$ of water (egg density was about $2.6 \mathrm{~g} / \mathrm{L}$ ). Hatching compartments were contained within each of five experimental hatching troughs described by Mitchell et al. (2009). Three smaller samples (13.1 \pm $1.6 \mathrm{~g}$ ) were also taken from each egg mass to determine egg number per gram in each spawn, which allowed us to calculate the number of eggs based on weight in each compartment. Egg number was then compared with the number of viable hatched fry counted per compartment to calculate the percent hatch. Well water inflow to each compartment was about $1.25 \mathrm{~L} / \mathrm{min}$ and produced about 2 water exchanges/h. This exchange rate is comparable to industry averages for troughs (Steeby and Avery 2005).

Immersion-flush treatments of hydrogen peroxide ( $250 \mathrm{mg}$ of $\mathrm{H}_{2} \mathrm{O}_{2} / \mathrm{L}$ of water; Perox-Aid, $35 \% \mathrm{H}_{2} \mathrm{O}_{2}$; Eka Chemicals, Göteborg, Sweden), formalin ( $434 \mathrm{mg} /$ L; formaldehyde, 37\%; ACROS Organics, Geel, Belgium), CSP $\left(10 \mathrm{mg}\right.$ of $\mathrm{CuSO}_{4} \cdot 5 \mathrm{H}_{2} \mathrm{O}$ per liter; Triangle Brand; Freeport-McMoRan Copper and Gold, Inc., Phoenix, Arizona), and diquat bromide ( $25 \mathrm{mg}$ of diquat cation/L; Reward herbicide; Syngenta Crop Protection, Inc., Greensboro, North Carolina) were applied once daily at 24-h intervals. Copper sulfate pentahydrate was applied until the eyed egg stage of 
development was attained, but all other treatments were applied until hatching began.

The trials were set up in a Latin square design to minimize trough and spawn effects (Norman and Streiner 2000). Specifically, egg portions were randomly assigned to treatments and hatching troughs such that one portion from each spawn was distributed to each trough, and the control and each of the four chemical treatments were randomly assigned to a portion of each spawn. In this manner, a portion of each egg mass was subjected to every treatment and to a control.

Trials were conducted at water temperatures of (mean $\pm \mathrm{SD}) 23.4 \pm 0.3^{\circ} \mathrm{C}$ and dissolved oxygen concentrations of $5.6 \pm 0.6 \mathrm{mg} / \mathrm{L}$ ( $65 \%$ saturation) measured with a pH/Oxi 340i/SET meter (Wissenschaftlich-Technische Werkstätten GmbH, Weilheim, Germany). An Accumet Basic AB15 pH meter (Fisher Scientific, UE Tech Park, Singapore) was used to measure $\mathrm{pH}$ (7.4-7.7), and standard titration methods (APHA et al. 2005) were used to measure total alkalinity $(204 \pm 11 \mathrm{mg} / \mathrm{L}$, as $\left.\mathrm{CaCO}_{3}\right)$ and total hardness $\left(121 \pm 3 \mathrm{mg} / \mathrm{L}\right.$, as $\left.\mathrm{CaCO}_{3}\right)$.

A single water sample was taken from each replicate of each chemical treatment at midwater depth near the egg basket approximately $30 \mathrm{~s}$ after adding the chemical treatments on the fifth day of trial 2 as described by Straus et al. (2009). Water samples were analyzed for (1) $\mathrm{H}_{2} \mathrm{O}_{2}$ concentration by using a colorimetric titration method according to Solvay Chemicals Technical Data Sheet 3047-HH-1221 (www.solvaychemical.com), (2) formaldehyde by using a spectrophotometric method according to Hach 3-methyl-2-benzothiaoline hydrazone Method 8110 (Hach Co., Loveland, Colorado), (3) copper by using a spectrophotometric method according to standard methods (APHA et al. 2005) with a PerkinElmer inductively coupled plasma-optical emission spectrometer (PerkinElmer, Inc., Waltham, Massachusetts), and (4) diquat cation by using a liquid-solid extraction and high-performance liquid chromatography with ultraviolet detection according to U.S. Environmental Protection Agency Method 549.1 (http://www.strataspe.com/speapps/environ/ EPA\%20549_1\%20Generic.pdf). Copper and formaldehyde concentrations were multiplied by 3.93 and 2.70, respectively, to give final concentrations of CSP and formalin.

Natural fungal infestations common to our waters and spawning facility that were found on the egg portions in each compartment were recorded daily until hatching. The diameter of the largest single fungal mass was measured to the nearest $0.5 \mathrm{~cm}$ and recorded daily. At the end of each trial, the maximum measure from each egg portion was selected for comparison. A measure of $9-11 \mathrm{~cm}$ was indicative of complete egg portion coverage. The average maximum fungal measure of growth and fungal occurrence ([number of egg portions with fungal growth/total number of egg portions in a treatment or control] $\times 100$ ) were determined for each treatment in both trials.

Potential fungal samples observed on the egg masses from all the controls in both trials were taken with forceps and divided into three subsamples. The first was used to presumptively identify aquatic fungi by microscopically $(20 \times)$ confirming whether cottonlike masses contained numerous branched hyphae and zoosporangia. The other two samples were either placed in vials containing 95\% molecular-grade ethanol or cultured on yeast peptone sucrose agar containing streptomycin sulfate and chloramphenicol. Final identification of fungal species was confirmed by polymerase chain reaction (PCR; White et al. 1990; Mitchell et al. 2009; Straus et al. 2009b).

To determine whether data sets from the two trials could be combined, percent hatch and fungal maximum measures in the two replicate trials were compared using the general linear model to perform a one-way analysis of variance (ANOVA) in Minitab version 13 (Minitab, Inc., State College, Pennsylvania). Chemical treatment, trial, and the trial $\times$ treatment interaction term were included as factors in the model. As trial and trial $\times$ treatment interaction effects were not significant, data from the two trials were combined in the final determination of differences among treatment means. Log-transformed data for percent hatch and fungal maximum measure were normally distributed with equal variances (Anderson-Darling normality test and Levene's test for equal variances in Minitab); therefore, ANOVA was performed on the log-transformed data. Differences among treatment means were separated using the Tukey-Kramer procedure for pairwise comparisons (J. W. Tukey, Princeton University, unpublished; Kramer 1956). All treatment effects were considered significant at $P$-values less than 0.05 .

\section{Results and Discussion}

All fungal samples taken from the egg portions were presumptively identified as aquatic fungi. Four of 10 samples were identified by PCR as Saprolegnia spp. (University of North Carolina at Wilmington [UNCW] isolates 273 and 286) when compared with those in GenBank. Six of the samples could not be sequenced after two attempts. The UNCW numbers are isolate groupings based on the work of Hulvey et al. (2007).

The percent hatch in the control group was significantly $(F=3.79$; df $=8 ; P=0.003)$ lower than that observed in the diquat bromide, formalin, $\mathrm{H}_{2} \mathrm{O}_{2}$, and CSP treatment groups (Table 1). The mean fungal coverage measure of the control group was signifi- 
TABLE 1.-Mean (SE) percent channel catfish hatch (egg survival) in a control group and four chemical treatment groups $(n=9)$ : copper sulfate pentahydrate $(10 \mathrm{mg} / \mathrm{L})$, diquat bromide ( $25 \mathrm{mg}$ of diquat cation/L), formalin $(433 \mathrm{mg} / \mathrm{L})$, and hydrogen peroxide $(250 \mathrm{mg} / \mathrm{L})$. Mean (SE) maximum fungal coverage measure (largest measured diameter of a fungal mass on eggs) for controls and chemical treatments $(n=10)$ is also shown. Means followed by different letters are significantly different $(P \leq 0.05)$.

\begin{tabular}{lll}
\hline \multicolumn{1}{c}{ Treatment } & $\begin{array}{c}\text { Mean percent } \\
\text { hatch }\end{array}$ & $\begin{array}{c}\text { Mean fungal } \\
\text { coverage }(\mathrm{cm})\end{array}$ \\
\hline Control & $34.0(9.6) \mathrm{z}$ & $7.2(1.1) \mathrm{z}$ \\
Copper sulfate & $55.3(6.3) \mathrm{y}$ & $2.9(0.9) \mathrm{y}$ \\
Diquat bromide & $55.7(8.0) \mathrm{y}$ & $3.9(1.0) \mathrm{yz}$ \\
Formalin & $56.6(7.7) \mathrm{y}$ & $3.0(1.0) \mathrm{y}$ \\
Hydrogen peroxide & $64.1(6.9) \mathrm{y}$ & $1.5(0.8) \mathrm{y}$ \\
\hline
\end{tabular}

cantly $(F=5.84 ; \mathrm{df}=9 ; P=0.001)$ larger than those of the CSP, formalin, and $\mathrm{H}_{2} \mathrm{O}_{2}$ treated groups but not different from that of the diquat bromide treated group (Table 1). Percent hatch and fungal coverage were not significantly different among chemical treatment groups. An $\mathrm{H}_{2} \mathrm{O}_{2}$ treatment of $250 \mathrm{mg} / \mathrm{L}$ produced the numerically highest percent hatch $(64 \%$; control hatch $=34 \%$ ), the lowest fungal coverage measure (1.5 $\mathrm{cm}$; control coverage $=7.2 \mathrm{~cm}$; Table 1$)$, and the lowest occurrence of fungi $(50 \%$; control occurrence $=$ $100 \%$ ). The occurrence of fungi in the CSP, diquat bromide, and formalin treatment groups was 70, 90, and $80 \%$, respectively.

Only 9 of the 10 replicates were analyzed for percent hatch because all hatched fry (dead and alive) were missing from the compartment in one of the treatments of the fourth replicate in trial 1. All treatments in this replicate were therefore excluded from analysis for percent hatch. We have no explanation for the missing fry: the day before hatching was completed and fry were collected and preserved for counting, numerous hatched healthy fry were seen in the compartment. Data collection for maximum fungal measures, however, was completed before the disappearance of hatching fry, and all 10 replicates were included.

All egg portions from one spawn used for trial 2 were heavily infested with fungi $(5-8 \mathrm{~cm})$ regardless of treatment. Some factors potentially affecting the fungal infestations of given spawns include (1) innate immunity of the eggs, (2) prior exposure of eggs to fungal spores, and (3) amount of unfertilized or dead eggs, which provide a good nutrient base for fungal growth (Tucker and Robinson 1990) within the spawns. In previous studies, the initiation of fungal growth was observed on egg masses in which a small group of dead eggs (2-10) was present (Mitchell et al. 2009).
The measured diquat cation concentrations ranged from 22.5 to $29.8 \mathrm{mg} / \mathrm{L}$ (average $=26.3 \mathrm{mg} / \mathrm{L}$ ) and were within a maximum of $19.2 \%$ from nominal (25 $\mathrm{mg} / \mathrm{L}$ ). Formalin concentrations ranged from 432 to $486 \mathrm{mg} / \mathrm{L}$ (average $=455.8 \mathrm{mg} / \mathrm{L}$ ) and were within a maximum of $12.0 \%$ from nominal $(433 \mathrm{mg} / \mathrm{L})$. The concentrations of CSP ranged from 9.1 to $10.5 \mathrm{mg} / \mathrm{L}$ (average $=9.7 \mathrm{mg} / \mathrm{L}$ ) and were within a maximum of $9.2 \%$ from nominal $(10 \mathrm{mg} / \mathrm{L})$. The $\mathrm{H}_{2} \mathrm{O}_{2}$ concentrations ranged from 245 to $301 \mathrm{mg} / \mathrm{L}$ (average $=264.3$ $\mathrm{mg} / \mathrm{L}$ ) and were within a maximum of $17.0 \%$ from nominal $(250 \mathrm{mg} / \mathrm{L})$. These differences between the measured and nominal chemical concentrations could be due to errors in analytical techniques associated with the dilution of samples or, in some cases, might have been caused by binding of the chemical to organic matter in the test system. Alternatively, chemicals may not have evenly mixed in the water column during the 30 -s period between chemical addition and sample collection.

Some of the rates chosen for the treatments in this study differed from the optimal treatment rates determined in other studies that used different test systems and modes of chemical delivery (Rach et al. 1998, 2004; Small and Wolters 2003) and from the FDA-labeled rates for use on warmwater finfish eggs. A valid comparison can be made of the treatments in one test system where they are subjected to the same test conditions. In our system, all four treatments were subjected to similar conditions except that the CSP treatment was stopped at the eyed stage, whereas the other treatments continued until hatch. The CSP treatment was stopped at the eyed stage because the applications of CSP in previous range-finding and dose confirmation studies (Straus et al. 2009a, 2009b) were also made only until eggs were eyed. The rationale used by Straus et al. (2009a, 2009b) to stop treatments at the eyed stage was that some embryos within the same rearing unit may be hatching and the CSP dose might be toxic to the fry (Straus 2008). The difference in duration among chemical treatments in this case, however, is minimal as the CSP treatments were applied for $5 \mathrm{~d}$ (trial 1) and $6 \mathrm{~d}$ (trial 2) compared with $7 \mathrm{~d}$ for all other treatments in trials 1 and 2. If the CSP treatments had continued until hatch, a greater percent hatch may have resulted. After the last CSP treatment and prior to hatch, the fungal coverage measure increased an average of only $0.15 \mathrm{~cm}$ (fungal measures in 3 of 10 spawn portions each increased by $0.5 \mathrm{~cm}$ ); therefore, continuing CSP treatments until hatch would probably offer little further benefit in controlling fungal growth.

All four treatments proved effective in increasing the percent hatch, and all treatments but diquat bromide 
significantly reduced fungal coverage. Although not statistically different from other treatments, $\mathrm{H}_{2} \mathrm{O}_{2}$ deserves further investigation because (1) it is one of two chemicals that has an FDA label for use on finfish eggs (the other, formalin, is a suspected carcinogen and may have other health concerns; Kerns et al. 1983) and (2) it had the numerically highest average survival (7.5-8.8\% more than the other treatments; Table 1), the lowest fungal coverage (numerically), and the lowest fungal occurrence among treatments. Further study is needed to assess the most effective $\mathrm{H}_{2} \mathrm{O}_{2}$ concentration for an immersion-flush treatment in commercial hatching troughs with a high egg density of approximately $18 \mathrm{~g} / \mathrm{L}$ (high rate used in channel catfish hatcheries, as calculated from Tucker and Robinson 1990). Rach et al. (2004) determined that optimum $\mathrm{H}_{2} \mathrm{O}_{2}$ application rates were $500-750 \mathrm{mg} / \mathrm{L}$ for an egg density of about $130 \mathrm{~g} / \mathrm{L}$. Therefore, a target $\mathrm{H}_{2} \mathrm{O}_{2}$ testing range between 250 and $750 \mathrm{mg} / \mathrm{L}$ may provide optimum rates for commercial hatching troughs. Research done on channel catfish eggs in a number of different systems and under different methods of application (Rach et al. 1998, 2004; Small and Wolters 2003; Small 2004; Mitchell et al. 2009) suggests that $\mathrm{H}_{2} \mathrm{O}_{2}$ is effective under a variety of egg hatching conditions. The further testing of $\mathrm{H}_{2} \mathrm{O}_{2}$ in once-daily and twice-daily static-bath immersion, continuous-flow immersion, and immersion-flush applications may result in treatment protocols that increase percent hatch and reduce fungal growth.

The chemical treatment rates used in our studies were based primarily on what was effective in previous range-finding trials with channel catfish eggs in our experimental hatching system and were also based on the results of other researchers who studied the efficacy of treatments on channel catfish eggs. It is recognized that what works optimally in our system may not be optimal for other test systems. The rates used for formalin $(433 \mathrm{mg} / \mathrm{L})$ and $\mathrm{H}_{2} \mathrm{O}_{2}(250 \mathrm{mg} / \mathrm{L})$ in our studies differ from those used by other researchers and are less than the rates appearing on labeled recommendations. The FDA-labeled recommendations are broad, encompass eggs from several fish species, and were derived from tests that used hatching systems other than troughs and application methods other than the immersion flush. It should not be surprising that some modifications may be required for a given species in a given system. The optimum rates in this study are not intended as recommendations but rather as a report of what works best within the parameters of our testing procedures. Our testing procedures were similar to the trough hatching procedures of commercial producers in that both utilize immersion-flush treatments, comparable water exchange rates, paddle wheels for egg movement and aeration, and baskets to contain egg mass portions. Two notable differences (because of study design and egg availability) were the use of compartmentalized troughs and the use of egg densities lower than those used by the industry. Further efficacy studies in commercial channel catfish trough hatching systems at industry stocking rates would have to be done before there is any consideration for recommending new rates or for changing the labels on approved products. Until such studies have been completed and until new rates have been approved and labeled, we do not suggest any modification to the existing labeled recommendations. Culturists in the USA are encouraged only to apply drugs approved by the FDA and only at rates specified on FDA-approved drug labels unless prescribed otherwise by a licensed veterinarian.

\section{Acknowledgments}

The authors thank U.S. Department of Agriculture (USDA) Agricultural Research Service (ARS) technicians Matt Barnett and Cindy Ledbetter as well as ARS summer interns Christen Proctor and Brandon Clemons for their superior and dedicated technical assistance throughout the course of the study. We are also grateful to our colleagues Steve Rawles (ARS), Brian Small (ARS), Mark Gaikowski (U.S. Geological Survey), and Steve Lochmann (University of Arkansas at Pine Bluff) for constructive comments and review of early manuscripts. This study was funded by USDA-ARS under Project Number 6225-32000-004-00D. Reference to trade names does not imply endorsement by the U.S. Department of Agriculture.

\section{References}

APHA (American Public Health Association), American Water Works Association and Water Pollution Control Federation. 2005. Standard methods for the examination of water and wastewater, 21st edition. APHA, Washington, D.C.

Gaikowski, M. P., J. J. Rach, M. Drobish, J. Hamilton, T. Harder, L. A. Lee, C. Moen, and A. Moore. 2003. Efficacy of hydrogen peroxide in controlling mortality associated with saprolegniasis on walleye, white sucker, and paddlefish eggs. North American Journal of Aquaculture 65:349-355.

Hulvey, J. P., D. E. Padgett, and J. C. Bailey. 2007. Species boundaries within Saprolegnia (Saprolegniales, Oomycota) based on morphological and DNA sequence data. Mycologia 99:421-429.

Kerns, W. D., K. L. Pavkov, D. J. Donofrio, E. J. Gralla, and J. A. Swenberg. 1983. Carcinogenicity of formaldehyde in rats and mice after long-term inhalation exposure. Cancer Research 43:4380-4392.

Kramer, C. Y. 1956. Extension of multiple range tests to group means with unequal numbers of replications. Biometrics 12:307-310.

Mitchell, A. J. 1983. Potential new fungicides for use on fish 
eggs. Fifth Annual Proceedings, Catfish Farmers of America, research workshop. U.S. Fish and Wildlife Service, Stuttgart, Arkansas.

Mitchell, A. J., A. A. Radomski, D. L. Straus, and R. Carter. 2009. The effect of hydrogen peroxide on the hatch rate of channel catfish eggs and on Saprolegnia spp. infesting channel catfish eggs. North American Journal of Aquaculture 71:276-280.

Neish, G. A., and G. C. Hughes. 1980. Diseases of fishes, book 6: fungal diseases of fishes. T.F.H. Publications, Neptune, New Jersey.

Norman, G. R., and D. L. Streiner. 2000. Biostatistics, the bare essentials. B.C. Decker, Hamilton, Ontario.

Rach, J. J., M. P. Gaikowski, G. E. Howe, and T. M. Schreier. 1998. Evaluation of the toxicity and efficacy of hydrogen peroxide treatments on eggs of warm- and coolwater fishes. Aquaculture 165:11-25.

Rach, J. J., J. J. Valentine, T. M. Schreier, M. P. Gaikowski, and T. C. Crawford. 2004. Efficacy of hydrogen peroxide to control saprolegniasis on channel catfish (Ictalurus punctatus) eggs. Aquaculture 238:135-142.

Small, B. C. 2004. Accounting for water temperature during hydrogen peroxide treatment of channel catfish eggs. North American Journal of Aquaculture 66:162-164.

Small, B. C., and W. R. Wolters. 2003. Hydrogen peroxide treatment during egg incubation improves channel catfish hatching success. North American Journal of Aquaculture 65:314-317.
Steeby, J., and J. Avery. 2005. Channel catfish broodfish and hatchery management. Southern Regional Aquaculture Center, Publication 1803, Stoneville, Mississippi.

Straus, D. L. 2008. Copper sulfate toxicity to channel catfish fry: yolk-sac fry versus swim-up fry. North American Journal of Aquaculture 70:323-327.

Straus, D. L., A. J. Mitchell, R. R. Carter, and J. A. Steeby. 2009a. Optimizing copper sulfate treatments for fungus control on channel catfish eggs. Journal of Aquatic Animal Health 21:91-97.

Straus, D. L., A. J. Mitchell, A. A. Radomski, R. R. Carter, and J. A. Steeby. 2009b. Laboratory dose confirmation of copper sulfate for treating fungus on channel catfish eggs. North American Journal of Aquaculture 71:333338 ,

Tucker, C. S., and E. H. Robinson. 1990. Channel catfish farming handbook. Van Nostrand Reinhold, New York

Walser, C. A., and R. P. Phelps. 1994. The use of formalin and iodine to control Saprolegnia infection on channel catfish, Ictalurus punctatus, eggs. Journal of Applied Aquaculture 3/4:269-278.

White, T. J., T. Grune, S. Lee, and J. Taylor. 1990. Amplification and direct sequencing of fungal rRNA genes for phylogenetics. Pages 315-322 in M. Innis, D. Gelfand, J. Shinsky, and T. White, editors. PCR protocols: a guide to methods and applications. Academic Press, New York. 